\title{
Decoying the $\mathrm{Cap}^{-}$mRNA Degradation System by a Double- Stranded RNA Virus and Poly(A) ${ }^{-}$mRNA Surveillance by a Yeast Antiviral System
}

\author{
DANIEL C. MASISON,${ }^{1}$ ANTONY BLANC, ${ }^{2}$ JUAN CARLOS RIBAS, ${ }^{1}$ KATHLEEN CARROLL,${ }^{1}$ \\ NAHUM SONENBERG ${ }^{2}$ AND REED B. WICKNER ${ }^{1 *}$ \\ Section on Genetics of Simple Eukaryotes, Laboratory of Biochemical Pharmacology, National Institute of Diabetes \\ and Digestive and Kidney Diseases, Bethesda, Maryland 20892, ${ }^{1}$ and Department of Biochemistry, \\ McGill University, Montreal, Quebec, Canada H3G $1 Y^{2}$
}

Received 15 December 1994/Returned for modification 14 February 1995/Accepted 22 February 1995

\begin{abstract}
The major coat protein of the L-A double-stranded RNA virus of Saccharomyces cerevisiae covalently binds $\mathrm{m}^{7}$ GMP from $5^{\prime}$ capped $\mathrm{mRNAs}$ in vitro. We show that this cap binding also occurs in vivo and that, while this activity is required for expression of viral information (killer toxin mRNA level and toxin production) in a wild-type strain, this requirement is suppressed by deletion of $S K I 1 / X R N 1 / S E P 1$. We propose that the virus creates decapped cellular mRNAs to decoy the $5^{\prime} \rightarrow 3^{\prime}$ exoribonuclease specific for cap ${ }^{-}$RNA encoded by $X R N 1$. The $S K I 2$ antiviral gene represses the copy numbers of the L-A and L-BC viruses and the 20S RNA replicon, apparently by specifically blocking translation of viral RNA. We show that $S K I 2, S K I 3$, and $S K I 8$ inhibit translation of electroporated luciferase and $\beta$-glucuronidase mRNAs in vivo, but only if they lack the $3^{\prime}$ poly(A) structure. Thus, L-A decoys the $S K I 1 / X R N 1 / S E P 1$ exonuclease directed at 5 ' uncapped ends, but translation of the L-A poly(A) ${ }^{-}$mRNA is repressed by Ski2,3,8p. The $S K I 2-S K I 3-S K I 8$ system is more effective against cap ${ }^{+}$ poly $(A)^{-}$mRNA, suggesting a (nonessential) role in blocking translation of fragmented cellular mRNAs.
\end{abstract}

The $5^{\prime}$ end of eukaryotic mRNA has a cap structure of the form $\mathrm{m}^{7} \mathrm{G} 5^{\prime} \mathrm{ppp5} 5^{\prime} \mathrm{Xp} . .$. , while the $3^{\prime}$ end is polyadenylated. Both of these structures are essential for efficient translation and mRNA stability, and the cap is important for splicing and transport of mRNA (reviewed in references 25 and 32).

The requirement for $5^{\prime}$ cap and $3^{\prime}$ poly(A) structure for translation in eukaryotic cells has forced RNA viruses to adopt a variety of tricks. Influenza virus, replicating in the cell nucleus, cleaves the methylated $5^{\prime}$ cap structure from nascent cellular mRNAs (43), and the viral RNA polymerase uses them as primers for synthesis of viral mRNA (5). The $3^{\prime}$ poly(A) structure is added by the viral polymerase repeatedly copying a $3^{\prime}$-subterminal oligo(U) sequence in the viral RNA (reviewed in reference 28). Bunyaviruses also appropriate caps from cellular mRNAs in the same manner $(2,41)$. Members of the family Reoviridae encode their own capping enzymes (11, $19)$, and the oligo(A) found in reovirions (10) may stimulate translation of the poly $(\mathrm{A})^{-}$reovirus mRNAs by removing poly(A) binding proteins from cellular mRNAs and thus negating their relative advantage as messages (38). Sindbis virus has a $5^{\prime}$ cap, synthesized by viral protein nsP1 (48), and has an encoded $3^{\prime}$ poly(A). Picornaviruses have an encoded $3^{\prime}$ poly(A) and lack 5' caps but have developed an internal ribosome entry site or ribosome landing pad, a special 5' structure that induces the ribosome to ignore the absence of a $5^{\prime}$ cap and start translation far from the $5^{\prime}$ end of the mRNA $(26,42)$. This mechanism is apparently also utilized by a coronavirus for translation of one of its mRNAs (33). Rhabdoviruses add a 5' cap and $3^{\prime}$ poly(A) to their transcripts (58). Here we describe two new types of virus-host interaction involving the $5^{\prime}$ cap and $3^{\prime}$ poly(A) structures.

\footnotetext{
* Corresponding author. Mailing address: Bldg. 8, Room 207, National Institutes of Health, Bethesda, MD 20892-0830. Phone: (301) 496-3452. Fax: (301) 402-0240. Electronic mail address: wickner@ helix.nih.gov.
}

The genome of the L-A double-stranded RNA (dsRNA) virus of Saccharomyces cerevisiae lacks both the 5' cap and $3^{\prime}$ poly(A) $(6,54)$. Its cytoplasmic location (12) makes it unlikely that it can use cellular enzymes to modify its mRNA, and viral transcripts made in vitro lack both modifications, although a single uncoded A (or $\mathrm{G}$ ) residue is found at the $3^{\prime}$ end of both viral strands $(7,54)$.

L-A has a single 4.6-kb segment encoding the major viral coat protein (Gag) and a multifunctional Pol expressed only as a Gag-Pol fusion protein formed by a -1 ribosomal frameshift $(13,18,24) \cdot M_{1}$, a satellite dsRNA of L-A, encodes a secreted protein toxin (the killer toxin) that kills cells not carrying $M_{1}$ (reviewed in reference 8). Because $M_{1}$ is packaged and replicated by the L-A-encoded proteins, this killer phenotype has been used to examine the genetics of the helper virus, L-A. The $M A K$ chromosomal genes are necessary for the maintenance of killer dsRNA $\left(\mathrm{M}_{1}\right)$; mutations of several $M A K$ genes result in loss of L-A as well, and others are known to decrease the copy number of L-A (reviewed in references 40 and 59).

The $S K I$ genes, named for the superkiller phenotype of the mutants, have been proposed to be a cellular antiviral system because $S K I 2, S K I 3$, and SKI8 are essential to the cell only for repressing viral propagation $(14,35,44,45,51,62)$. The products of the $S K I 2,-3,-4,-6,-7$, and -8 genes repress the copy number of $\mathrm{M}_{1}$, and $S K I 2$ has also been shown to repress those of L-A, the L-BC dsRNA virus, and the 20S RNA singlestranded RNA (ssRNA) replicon $(1,34,45,56)$. Ski3p is a $163-\mathrm{kDa}$ nuclear protein with the TPR repeat pattern $(44,49)$. Ski2p is $145 \mathrm{kDa}$ and has helicase motifs and a glycine-arginine-rich region, suggesting that it may be nucleolar (62). A human Ski2p (hSki2p) 62\% identical to yeast Ski2p (31) has recently been identified. hSki2p has been shown by immunofluorescence studies to be localized to the nucleolus (31). Ski8p is $44 \mathrm{kDa}$ and has the WD repeat pattern first identified in $\beta$-transducins (35).

Analysis of the effects of a ski2 mutation on L-A and $\mathrm{M}_{1}$ 
propagation led to the suggestion that Ski2p affects virus propagation by partially blocking translation of viral mRNAs, possibly recognizing either their lack of the $5^{\prime}$ cap or of $3^{\prime}$ poly(A) structure (62). In support of this proposal, it was found that ski2-2 strains were derepressed threefold for synthesis of $\beta$-galactosidase from an RNA polymerase I transcript, expected to lack both the cap and poly(A) (62).

While ski1 mutants are superkillers like $s k i 2,-3$, and -8 , they apparently do not have elevated $\mathrm{M}_{1}$ dsRNA copy number and result in slow growth of the cell (56). Recently, A. Johnson and $\mathrm{R}$. Kolodner have shown that $S K I 1$ is identical to $S E P 1=$ $X R N 1=K E M 1=D S T 2=R A R 5$, encoding a $5^{\prime} \rightarrow 3^{\prime}$ exoribonuclease specific for uncapped RNA $(23,27,29,30,52,55)$. Mutation of $S K I 1 / X R N 1 / S E P 1$ results in increased levels of uncapped and non-poly(A) mRNA $(23,37)$. Because L-A and $\mathrm{M}_{1}(+)$ strands are uncapped (6), it is likely that the superkiller phenotype of skil mutants is due to prolonged survival and thus improved translation of these $(+)$ strand species.

In a search for cap-binding proteins in $S$. cerevisiae (3), it was found that the L-A major coat protein, Gag, and the L-BC major coat protein each become covalently attached in vitro to the $5^{\prime}$ cap structure of a completely heterologous mRNA, producing a decapped mRNA in the process. The $\mathrm{m}^{7} \mathrm{GMP}$ of the cap structure becomes covalently attached to His-154 of $\mathrm{Gag}$ in a reaction that requires only $\mathrm{Mg}^{2+}$ (4). An L-A cDNA clone which can support the expression and propagation of the $M_{1}$ satellite dsRNA encoding the killer toxin in vivo (60) was used to study the importance of the covalent cap-binding reaction (4). Mutants of the L-A cDNA clone in which His-154 had been changed to Asn, Arg, or Ser produced virus particles unable to covalently bind the $5^{\prime}$ cap in vitro. These mutants were still able to support the propagation of the $\mathrm{M}_{1}$ dsRNA at normal copy number but were markedly defective in expressing the killer toxin (4).

Our work brings together the study of the mechanism of action of the SKI genes and the in vivo role of cap binding by Gag. Our data show that Gag can remove 5' cap structures from cellular mRNA in vivo. Although this activity is essential for expression of $\mathrm{M}_{1}$ dsRNA-encoded killer toxin in a wildtype host, it is dispensable in a mutant defective in skil, suggesting that its purpose is to subvert Xrn1p (=Ski1p), a 5' $\rightarrow 3^{\prime}$ exoribonuclease that degrades such capless RNAs. The L-A virus thus (partially) hides its capless head in an excess of uncapped cellular mRNAs, but translation of L-A viral mRNA, because it lacks a poly(A) tail, is nonetheless specifically inhibited by the SKI2-SKI3-SKI-8 system.

\section{MATERIALS AND METHODS}

Strains and materials. The $S K I^{+}$and ski2 yeast strains used, strain 3221 and strain 3221 with the $s k i 2:: H I S 3$ disruption, were previously described (62). The ski8::URA3 disruption was constructed in strain JR1 (4) with the disruption plasmid previously described (51). The ski1::URA3 disruption derivative of strain JR1 (4) was constructed with pRDK227 (55) digested with AseI. The Ura ${ }^{+}$ disruptants were checked by Southern blotting. Strain 1320 (MATa met5 lys 2 his 7 mak7-1 ski2-3 can1) was made $S K I^{+}$by introduction of $\mathrm{p} 498$, the $S K I 2$ gene on a HindIII-SalI fragment carried on pRS316 (62). The killer test was carried out as described previously (45). The strains used for the in vivo Gag-cap linkage experiment were 1773 (MATa arg9 L-A-o L-BC-o M-o) and 1774 (MATa arg9 L-A-HN L-BC-o M-o) (50). Luciferin, cycloheximide, and 4-methylumbelliferyl$\beta$-D-glucuronide were obtained from Sigma and the luciferase assay kit from Promega. $\left[\alpha-{ }^{32} \mathrm{P}\right] \mathrm{GTP}$ and $\left[\alpha-{ }^{32} \mathrm{P}\right] \mathrm{UTP}$ were from DuPont-New England Nuclear. Plasmid pTIL131 (60) and its derivatives with substitutions at His-154 of Gag (4) have been described previously. p596 is Bluescript $\mathrm{KS}+$ with the $1.3-\mathrm{kb}$ Pst I-SalI fragment of $\mathrm{pP}-\mathrm{T}_{316}(63)$ carrying $\mathrm{M}_{1}$ sequences inserted between the PstI and SalI sites.

Expression of luciferase and $\boldsymbol{\beta}$-glucuronidase mRNAs. The luciferase and glucuronidase mRNA expression plasmids T7 LUC [poly(A) ${ }^{-}$], T7 LUC $_{50}$ [50mer poly(A) tail], T7 GUS [poly(A) ${ }^{-}$], and T7 GUS 50 [50-mer poly(A) tail] have been described previously (21). For RNA synthesis, T7 LUC and T7 GUS were

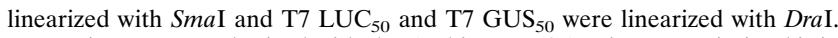
Transcripts were synthesized with the Ambion MEGAscript transcription kit in the presence or absence of the cap analog $5^{\prime} \mathrm{m}^{7} \mathrm{GpppG}$ according to the manufacturer's instructions. After DNase I treatment followed by extraction with phenol-chloroform and precipitation with isopropanol, RNA was quantitated by both measuring optical density at $260 \mathrm{~nm}\left(\mathrm{OD}_{260}\right)$ and comparison on agarose gels with known concentration standards.

RNA electroporation was done by the procedure described by Everett and Gallie (15) with minor modifications. Two micrograms of RNA was used for electroporations, and cells were assayed for luciferase or glucuronidase activity after $3 \mathrm{~h}$ of outgrowth at $30^{\circ} \mathrm{C}$. For luciferase assays, spheroplasts were collected by centrifugation, suspended in $100 \mu \mathrm{l}$ of LAB (46), and lysed by vortexing vigorously for $30 \mathrm{~s}$, and cell debris was pelleted by 5 to $10 \mathrm{~s}$ of microcentrifugation. Luciferase activity was assayed by adding $20 \mu \mathrm{l}$ of lysate to $200 \mu \mathrm{l}$ of luciferase assay reagent (Promega) and measuring luminescence in an LKB model 1250 luminometer. Glucuronidase assays were performed as described previously (15). Protein concentrations of all lysates were determined with the Bio-Rad protein assay kit.

In vivo Gag-cap linkage. The method of Russell et al. (46) was used to prepare yeast spheroplasts and to introduce RNA into them, except for the following modifications. Thawed spheroplasts were incubated with the RNA at room temperature for $15 \mathrm{~min}$, supplemented with $1 \mathrm{ml}$ of PEG solution $(20 \%$ polyethylene glycol $8000,10 \mathrm{mM}$ Tris- $\mathrm{HCl}$ [pH 7.5], $10 \mathrm{mM} \mathrm{CaCl}_{2}$ ) and further incubated for $20 \mathrm{~min}$ at room temperature. The spheroplasts were then gently collected by centrifugation, resuspended in $1 \mathrm{ml}$ of SOS medium (1 M sorbitol, $6.5 \mathrm{mM} \mathrm{CaCl}_{2}, 1 / 3 \times \mathrm{YPAD}$ [62]), allowed to recover for $20 \mathrm{~min}$ at $30^{\circ} \mathrm{C}$, collected again, chilled, and resuspended in $80 \mu \mathrm{l}$ of cold buffer B $(10 \mathrm{mM}$ HEPES [ $N$-2-hydroxyethylpiperazine- $N$ '-2-ethanesulfonic acid; $\mathrm{pH}$ 7.9], $1.5 \mathrm{mM}$ $\mathrm{MgCl}_{2}, 50 \mathrm{mM}$ EDTA, $10 \mathrm{mM} \mathrm{KCl}, 0.5 \mathrm{mM}$ phenylmethylsulfonyl fluoride, 50 mM EDTA). Chilled glass beads were added to just below the meniscus, and the tubes were vortexed four times for $30 \mathrm{~s}$ with 1 -min intervals on ice between. The homogenate was collected, spun at $16,000 \times g$ for 5 min at $4^{\circ} \mathrm{C}$, immediately supplemented with $40 \mu \mathrm{l}$ of sodium dodecyl sulfate (SDS)-mercaptoethanol protein sample buffer, and incubated for $5 \mathrm{~min}$ at $100^{\circ} \mathrm{C}$.

Stability of electroporated RNA. Luciferase reporter transcription reactions were done as described above, except that $3.2 \mathrm{mM} \mathrm{UTP}$ and $3 \mu \mathrm{Ci}$ of $\left[\alpha-{ }^{32} \mathrm{P}\right] \mathrm{UTP}$ $(3,000 \mathrm{Ci} / \mathrm{mmol})$ were used. Reaction mixtures were then treated with DNase I, extracted with phenol-chloroform, and passed over G-50 spin columns (Pharmacia). The specific activity of RNA was determined by measuring $\mathrm{OD}_{260}$ and liquid scintillation counting. Electroporation of wild-type and ski2 strains with the four luciferase RNAs was carried out as described above with $1.5 \times 10^{5} \mathrm{cpm}(2 \mu \mathrm{g})$ of RNA per electroporation. Immediately after electroporation, one-third of the cultures $(200 \mu \mathrm{l})$ were transferred to ice and the remainder of the cultures were incubated at $30^{\circ} \mathrm{C}$ with gentle shaking. Collected spheroplasts were washed twice with $0.5 \mathrm{ml}$ of $1 \mathrm{M}$ sorbitol, lysed by vortexing in $50 \mu \mathrm{l}$ of $0.1 \%$ SDS, extracted first with phenol-chloroform and then with chloroform-isoamyl alcohol (24:1), and frozen on dry ice. Additional samples $(200 \mu \mathrm{l})$ were removed after 1.5 and $3 \mathrm{~h}$ and treated similarly. RNA $(15 \mu \mathrm{l})$ was then analyzed by electrophoresis on $1.1 \%$ agarose gels in $0.5 \times$ TBE (45 mM Tris-borate [pH 7.5], $1 \mathrm{mM}$ EDTA). After photographing the gels, they were dried onto Amersham Hybond-N nylon membranes and exposed to Kodak XAR X-ray film.

$M_{1}$ RNA levels. Cells were grown in $100 \mathrm{ml}$ of $\mathrm{H}$-trp medium (62) at $30^{\circ} \mathrm{C}$ to an $\mathrm{OD}_{600}$ of 1.0, collected by centrifugation, and suspended in $700 \mu \mathrm{l}$ of breaking buffer (40) made $50 \mathrm{mM}$ in EDTA to dissociate polysomes. Cells were broken by vortexing with glass beads, and the low-speed supernatant was collected and diluted to $6 \mathrm{ml}$ with breaking buffer-EDTA. Debris was removed by centrifugation at 5,000 rpm for $5 \mathrm{~min}$, and viral particles were largely removed by a 90 -min centrifugation at $40,000 \mathrm{rpm}$ in a 50 Ti rotor. The supernatant was extracted first with phenol-1\% SDS, and then with phenol-chloroform, and finally with chloroform-isoamyl alcohol (24:1). Nucleic acids were precipitated twice with ethanol and dissolved in $400 \mu \mathrm{l}$ of $\mathrm{H}_{2} \mathrm{O}$. The $\mathrm{OD}_{260}$ of each sample was measured, and $30 \mu \mathrm{g}$ of each sample was analyzed by native agarose gel electrophoresis. After electrophoresis, the gels were treated with formaldehyde and formamide and RNA was transferred to Hybond-N nylon membranes and hybridized as described previously (36). The $\mathrm{M}_{1}(+)$ strand-specific probe was made with T3 RNA polymerase and $\left[\alpha-{ }^{32} \mathrm{P}\right] \mathrm{UTP}$ with $\mathrm{p} 596$ cut with $P s t \mathrm{I}$ used as a template.

\section{RESULTS}

Ski2p, Ski3p, and Ski8p repress translation of cap ${ }^{+}$ poly(A) ${ }^{-}$mRNA. L-A viral RNA is reported to be both uncapped (6) and poly $(\mathrm{A})^{-}(7,54)$. Ski2p represses viral propagation by blocking translation of viral RNAs, an effect hypothesized to be mediated through recognition of the absence of a cap, a poly(A) tail, or both (62). To determine the contribution of these structural elements in Ski2p-mediated translation effects, luciferase reporter mRNAs were synthesized with and without caps and poly(A) tails and assayed for expression in isogenic wild-type and ski2 strains by electroporation (15). We 
TABLE 1. Ski2p, Ski3p, and Ski8p restrict translation of poly(A) luciferase mRNA ${ }^{a}$

\begin{tabular}{|c|c|c|c|c|c|}
\hline \multirow{2}{*}{$\begin{array}{l}\text { Strain and } \\
\text { genotype }\end{array}$} & \multirow{2}{*}{ Expt } & \multicolumn{4}{|c|}{$\begin{array}{l}\text { Translation of electroporated luciferase mRNA } \\
\text { (light units } / \mu \mathrm{g} \text { of protein) }\end{array}$} \\
\hline & & $\mathrm{C}^{+} \mathrm{A}^{+b}$ & $\mathrm{C}^{+} \mathrm{A}^{-}$ & $\mathrm{C}^{-} \mathrm{A}^{+}$ & $\mathrm{C}^{-} \mathrm{A}^{-}$ \\
\hline \multirow[t]{4}{*}{$3221 \mathrm{SKI}^{+}$} & 1 & 30 & 0.55 & 2.0 & 0.17 \\
\hline & 2 & 23 & 0.35 & 1.0 & 0.10 \\
\hline & 3 & 20 & 0.34 & 1.2 & 0.11 \\
\hline & Avg & 24 & 0.41 & 1.4 & 0.13 \\
\hline \multirow[t]{4}{*}{3221 ski2::HIS3 } & 1 & 37 & 12 & 1.1 & 0.40 \\
\hline & 2 & 48 & 16 & 1.5 & 0.73 \\
\hline & 3 & 50 & 15 & 1.3 & 0.55 \\
\hline & Avg & 45 & 14 & 1.3 & 0.56 \\
\hline ski2/+ & & $1.9(1.0)^{c}$ & $34(18)$ & $0.9(0.5)$ & $4.3(2.3)$ \\
\hline \multirow[t]{3}{*}{$3221 \mathrm{SKI}^{+}$} & 1 & 19 & 0.35 & 1.5 & 0.15 \\
\hline & 2 & 28 & 0.29 & 1.1 & 0.18 \\
\hline & Avg & 24 & 0.32 & 1.3 & 0.17 \\
\hline \multirow[t]{3}{*}{3221 ski8::URA3 } & 1 & 87 & 45 & 6.1 & 3.6 \\
\hline & 2 & 93 & 36 & 5.4 & 2.7 \\
\hline & Avg & 90 & 41 & 5.8 & 3.2 \\
\hline ski8/+ & & $3.8(1.0)$ & $130(34)$ & $4.5(1.2)$ & $19(5.0)$ \\
\hline \multirow[t]{3}{*}{$2601 S K I^{+}$} & 1 & 11 & 0.32 & 0.75 & 0.11 \\
\hline & 2 & 15 & 0.25 & 0.83 & 0.11 \\
\hline & Avg & 13 & 0.29 & 0.79 & 0.11 \\
\hline \multirow[t]{3}{*}{2601 ski3::URA3 } & 1 & 21 & 9.6 & 0.91 & 0.46 \\
\hline & 2 & 22 & 12 & 0.67 & 0.55 \\
\hline & Avg & 22 & 11 & 0.79 & 0.51 \\
\hline ski3/+ & & $1.7(1.0)$ & $38(22)$ & $1.0(0.6)$ & $4.6(2.7)$ \\
\hline \multirow[t]{3}{*}{ JR1 $S K I^{+}$} & 1 & 33 & 1.3 & 2.4 & 0.33 \\
\hline & 2 & 34 & 1.4 & 2.6 & 0.34 \\
\hline & Avg & 34 & 1.4 & 2.5 & 0.34 \\
\hline \multirow[t]{3}{*}{ JR1 ski1::URA3 } & 1 & 45 & 1.0 & 3.4 & 0.34 \\
\hline & 2 & 71 & 1.4 & 1.4 & 0.47 \\
\hline & Avg & 58 & 1.2 & 2.4 & 0.38 \\
\hline ski1/+ & & $1.7(1.0)$ & $0.86(0.5)$ & $0.96(0.6)$ & $1.1(0.7)$ \\
\hline \multicolumn{6}{|l|}{ Mutant/wild type } \\
\hline ski2/+ & & $(1.0)$ & 18 & 0.5 & 2.3 \\
\hline ski3/+ & & $(1.0)$ & 22 & 0.6 & 2.7 \\
\hline ski8/+ & & $(1.0)$ & 34 & 1.2 & 5.0 \\
\hline ski1/+ & & $(1.0)$ & 0.5 & 0.6 & 0.7 \\
\hline
\end{tabular}

${ }^{a}$ Spheroplasts were electroporated with $2 \mu \mathrm{g}$ of luciferase reporter mRNAs, and luciferase activity was measured after $3 \mathrm{~h}$ of outgrowth as described in Materials and Methods. The blank in the luciferase assay was 0.001 light unit. Values are from at least two independent electroporations of two different spheroplast preparations for each strain. All strains lacked L-A and $\mathrm{M}_{1}$ viruses and L-A cDNA clones.

${ }^{b} \mathrm{C}^{+}$, capped; $\mathrm{C}^{-}$, uncapped; $\mathrm{A}^{+}$, $\operatorname{poly}(\mathrm{A})^{+} ; \mathrm{A}^{-}, \operatorname{poly}(\mathrm{A})^{-}$

${ }^{c}$ Values in parentheses have been normalized with respect to the values for the $\mathrm{C}^{+} \mathrm{A}^{+}$mRNA.

found that the ski2 mutation derepressed translation of $\operatorname{poly}(\mathrm{A})^{-}$message, with a greater effect seen for capped poly(A) ${ }^{-}$mRNA (18-fold) than for uncapped poly(A) mRNA (2.3-fold) (Table 1).

ski3 and ski8 mutants have phenotypes indistinguishable from that of ski2 (45), suggesting that they may act together to produce a common effect. Examination of isogenic pairs of ski3
TABLE 2. Ski2p restricts the translation of $\mathrm{Cap}^{+} \operatorname{poly}(\mathrm{A})^{-} \beta-$ glucuronidase mRNA

\begin{tabular}{|c|c|c|c|c|}
\hline \multirow{2}{*}{$\begin{array}{l}\text { Strain and } \\
\text { genotype }\end{array}$} & \multicolumn{4}{|c|}{$\begin{array}{l}\text { Translation of electroporated } \beta \text {-glucuronidase mRNA } \\
\text { (glucuronidase units } / \mu \mathrm{g} \text { of protein) }\end{array}$} \\
\hline & $\mathrm{C}^{+} \mathrm{A}^{+a}$ & $\mathrm{C}^{+} \mathrm{A}^{-}$ & $\mathrm{C}^{-} \mathrm{A}^{+}$ & $\mathrm{C}^{-} \mathrm{A}^{-}$ \\
\hline $3221 \mathrm{SKI}^{+}$ & 22.7 & 3.0 & 1.7 & $<0.3$ \\
\hline 3221 ski2::HIS3 & 12.4 & 24.1 & 1.1 & $<0.3$ \\
\hline ski2/+ & $0.55(1.0)^{b}$ & $8.0(14.5)$ & $0.64(1.2)$ & \\
\hline
\end{tabular}

and $\mathrm{SKI}^{+}$or $s k i 8$ and $S \mathrm{KI}^{+}$strains for their ability to translate the luciferase mRNAs showed patterns identical to that seen for ski2 (Table 1).

To test whether these effects were specific for luciferase mRNA, we carried out similar studies with $\beta$-glucuronidase. The results were qualitatively similar (Table 2), with a 14-fold increase in ski2 cells in expression of capped mRNA lacking poly(A) relative to that of $\operatorname{cap}^{+} \operatorname{poly}(\mathrm{A})^{+}$mRNA. However, the lower level of sensitivity of the assay made it impossible to determine whether there was an effect of SKI2 on translation on cap $^{-} \operatorname{poly}(\mathrm{A})^{-}$mRNA.

SKI2 does not primarily affect degradation of electroporated mRNA. We analyzed the physical and functional stability of electroporated RNAs to determine if degradation of the capped poly $(\mathrm{A})^{-}$message was contributing to the difference in its level of expression in ski2 and wild-type strains. An electroporation similar to that done for the expression assays was performed, but with radiolabeled luciferase transcripts (Materials and Methods). Electroporated RNA was analyzed at various times during the outgrowth period (Fig. 1). Similar patterns of degradation were seen for the four transcripts in both strains. We saw no differences in RNA stability between the two strains over the course of the experiment that would indicate that the cause of the difference in expression of the capped unpolyadenylated message was the degradation of this specific message by Ski2p.

The mRNAs lacking a cap or poly $(\mathrm{A})$ were expected to be less stable than mRNA having both structures, but no substantial differences were seen. This suggests that the cap ${ }^{-}$or $\operatorname{poly}(\mathrm{A})^{-}$mRNAs were in excess over the capacity of the degradative systems, that much of the mRNA was delivered by the electroporation to a compartment where these systems cannot degrade it, or that in the cells, as prepared for electroporation, these systems are relatively inactive.

We therefore examined the functional stability of the portion of the cap ${ }^{+}$poly(A)-deficient mRNA that was translated by examining the time course of luciferase synthesis in ski2, ski8, and wild-type cells (Fig. 2). The initial rates of synthesis were 4.5 - and 6.8-fold higher in ski2 and ski8 cells, respectively, than in wild-type cells, indicating that the primary effects of Ski2p and Ski8p were on the translation rate rather than on message stability. Synthesis ceased sooner in the wild-type cells than in the ski2 and ski8 cells, indicating a late effect on message stability, possibly secondary to the poor translation of the poly $(\mathrm{A})^{-}$mRNA in the wild-type cells.

ski2 suppresses mak7 without relieving deficiency of $60 \mathrm{~S}$ ribosomal subunits. The $M A K$ genes were defined by their inability to maintain $\mathrm{M}_{1}$ dsRNA. Mutations in 20 mak genes lead to diminished levels of free $60 \mathrm{~S}$ ribosomal subunits $(9,40)$. These mak mutations are suppressed by ski2 mutations (45, 57). We find that the ski2 mutation does not restore the normal 


\section{Electroporated RNA}

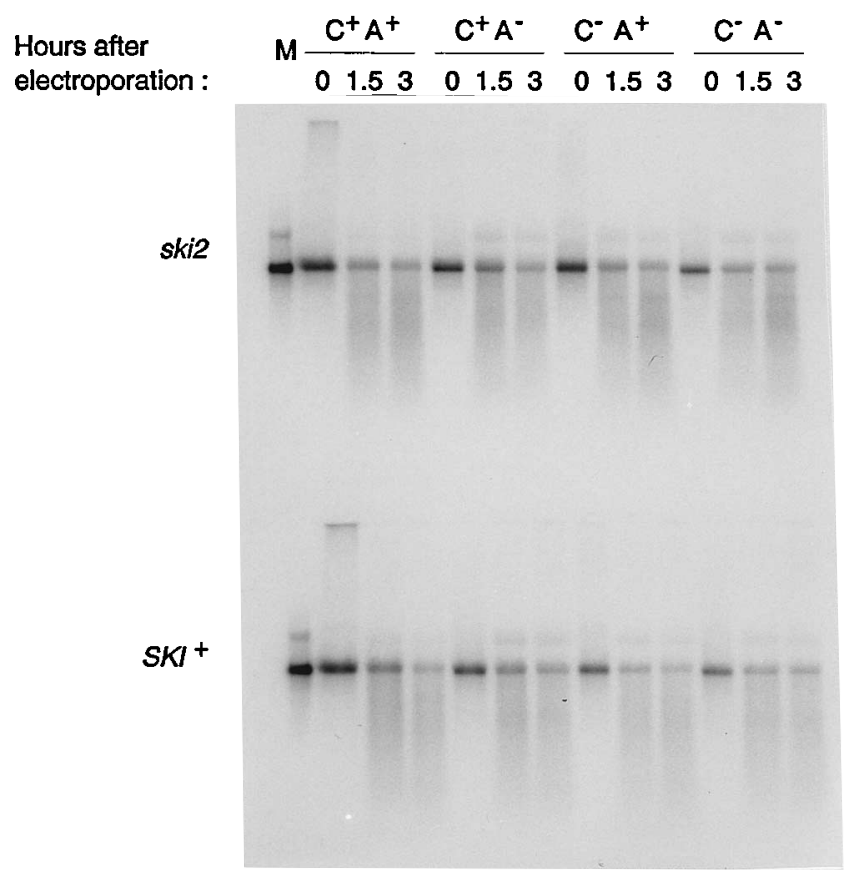

FIG. 1. Physical stability of luciferase reporter RNAs. Wild-type and ski2 strains were electroporated with radiolabeled luciferase transcripts, and at various times, RNA from electroporated cells was extracted and analyzed by gel electrophoresis and autoradiography as described in Materials and Methods. (Top) Electroporated ski2 cells. (Bottom) Electroporated $S K I^{+}$cells. Abbreviations are the same as those used for the legend to Table 1 . In both panels, lane 1 contains $500 \mathrm{cpm}$ of the uncapped poly $(\mathrm{A})^{-}$transcript.

level of $60 \mathrm{~S}$ subunits in suppressing the effect of a mak7 mutation on $\mathrm{M}_{1}$ propagation (Fig. 3).

Gag covalently binds cap structures in vivo. When purified L-A viral particles are incubated with RNA containing a cap structure in the presence of magnesium, the His-154 residue of

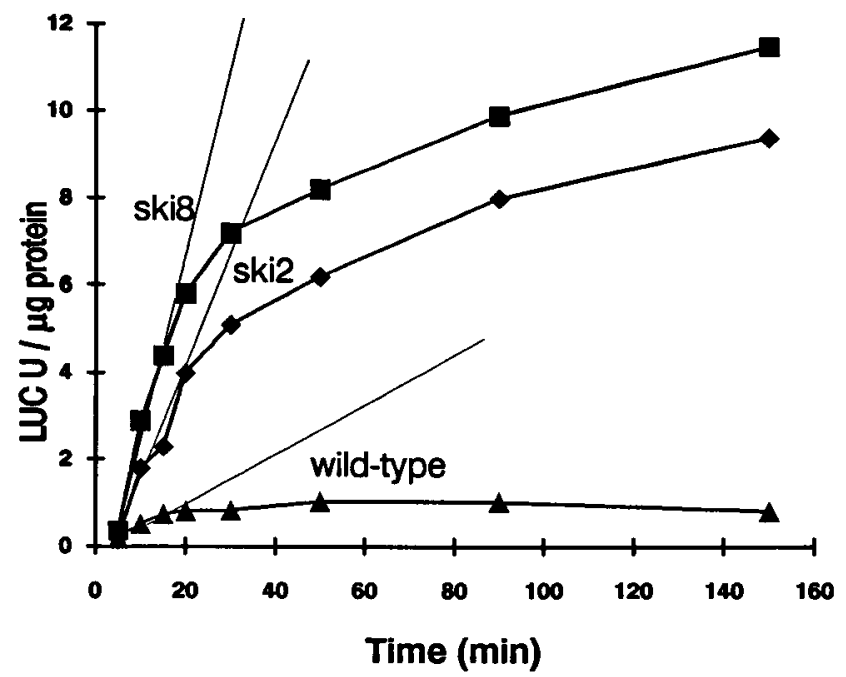

FIG. 2. Kinetics of luciferase accumulation from cap ${ }^{+}$poly(A) ${ }^{-}$mRNA in ski2, ski8, and wild-type cells. The time course of translation was examined to distinguish the effects of SKI2 and SKI8 on translation efficiency and the effects on mRNA functional half-life as described by Gallie (20). LUC U, luciferase units. the L-A Gag protein becomes covalently bound to the $\mathrm{m}^{7} \mathrm{GMP}$ cap, releasing the uncapped mRNA $(3,4)$. Mutations converting this residue to Arg, Asn, or Ser result in Gag proteins that bind caps but do not become covalently attached. This attachment was shown to be unnecessary for propagation of $\mathrm{M}_{1}$, but it is required for normal expression of the killer phenotype (4). To demonstrate that the linkage occurs in vivo, spheroplasts were electroporated with cap-labeled RNA, and labeled protein was detected by autoradiography of SDS-polyacrylamide gels. As seen in Fig. 4 (lane 2), a protein with the mobility of L-A Gag became labeled, indicating acquisition of the cap from the labeled RNA by the L-A viral particles. Labeling of Gag was not seen in a strain lacking L-A (lane 1) or when $\mathrm{m}^{7} \mathrm{GDP}$, a competitor of the linkage reaction (3), was included during the electroporation incubations (lane 3). Except for the Gag band (indicated by the arrow), all of the bands in Fig. 4 were removed by RNase treatment of the sample (not shown). We ensured that the linkage occurred while the spheroplasts were still intact by collecting them by centrifugation immediately prior to lysis; viral particles released and labeled before lysis would remain in the supernatant and be removed. We also lysed the spheroplasts in $50 \mathrm{mM}$ EDTA, which blocked subsequent linkage (3). An additional control showed that purified L-A particles added at the time the cells were broken did not become labeled (lane 4), indicating that the Gag-cap linkage occurred prior to disruption of the cells. Panel B of Fig. 4 shows that the amount of purified L-A virus added to spheroplasts of the strain lacking L-A in lane 4 of panel A is comparable to the amount in $\mathrm{L}_{-} \mathrm{A}^{+}$spheroplasts (compare lanes 2 and 3). This experiment indicates that linkage of Gag to cap structures is not restricted to in vitro conditions and that it also occurs in vivo.

Stolen caps are not transferred to nascent L-A transcripts in vitro. A possible physiological role for the cap-binding activity by Gag is to append the acquired caps to new viral $(+)$ strands, enhancing their translational efficiency, a mechanism used by several other viruses. The marked reduction in expression of the killer phenotype by strains expressing the His-154 mutations would then be explained by the inability of these proteins to transfer caps resulting in poorly expressed uncapped viral transcripts. Although genomic L-A and $\mathrm{M}_{1}$ RNAs have been reported to be uncapped (6), this hypothesis was attractive in light of the role established above for Ski2,3,8p in restricting translation of $\operatorname{cap}^{+}$poly $(\mathrm{A})^{-}$messages. We tested this hypothesis by including cap-labeled RNA in an in vitro transcription reaction using purified L-A viral particles. Products were analyzed on denaturing gels, the gels were dried, and autoradiograms were obtained. We were unable to detect transfer of the labeled cap from the 497-nucleotide capped RNA to the nascent L-A transcripts (4.6 kb) (data not shown).

skil suppresses the decapping requirement for expression of killer toxin. When the $M_{1}$ satellite RNA is supported by the L-A cDNA clone with a mutation of Gag His-154 to Asn, Arg, or Ser, the copy number of $\mathrm{M}_{1}$ dsRNA is the same as that for a wild-type Gag, but the killer toxin encoded by $M_{1}$ is expressed poorly (reference 4 and Table 3 ). When SKI1 is disrupted, we find that the expression of killer toxin returns to nearly the control level (Table 3 ). In contrast, disruption of SKI2 (4) or SKI8 (Table 3) had no effect on the expression of killer toxin.

That the ski1/xrn1 disruption suppresses the decapping requirement (Gag His-154 mutation) for $\mathrm{M}_{1}$ expression by relieving the degradation of $\mathrm{M}_{1}(+)$ strands was confirmed (Fig. $5)$. The Gag His-154 $\rightarrow$ Arg mutation results in lower levels of $\mathbf{M}_{1}(+)$ strands in the cell (Fig. 5, compare lanes 2 and 5). The skil mutation largely reverses that decrease (compare lanes 3 


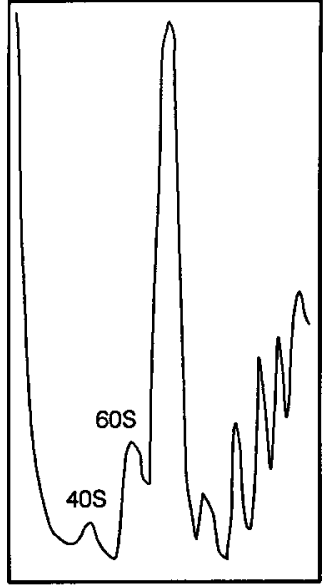

3221 SKI+

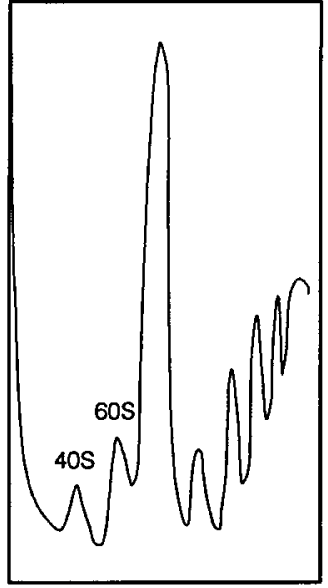

3221 ski2::HIS3

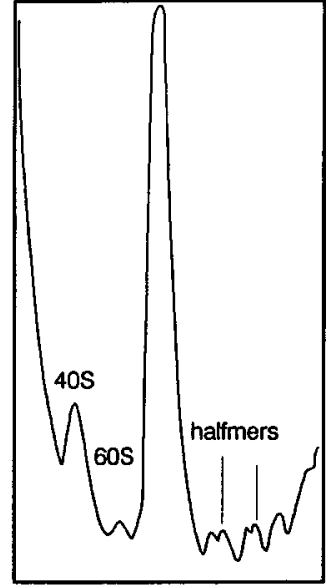

mak7 ski2 / pSKI2

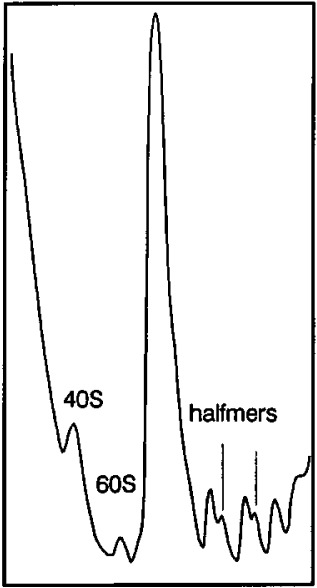

mak7 ski2

FIG. 3. The ski2::HIS3 mutation suppresses a mak7 (rpl4A) mutation for $\mathrm{M}_{1}$ propagation without affecting the deficiency of $60 \mathrm{~S}$ subunits produced by the mak7 mutation. Polysome gradients were carried out as described previously (22). The mak7 ski2 strain is strain 1320 , and an isogenic $S K I^{+}$derivative was made by introducing p498, the SKI2 gene, on a single-copy plasmid.

and 6), but a ski8 mutation has no such effect (compare lanes 4 and 7). In this experiment, a ski8 mutation did not alter the amount of $\mathrm{M}_{1}(+)$ ssRNA (compare lanes 2 and 4 or lanes 5 and 7), supporting our view, based on electroporated luciferase

\section{A}

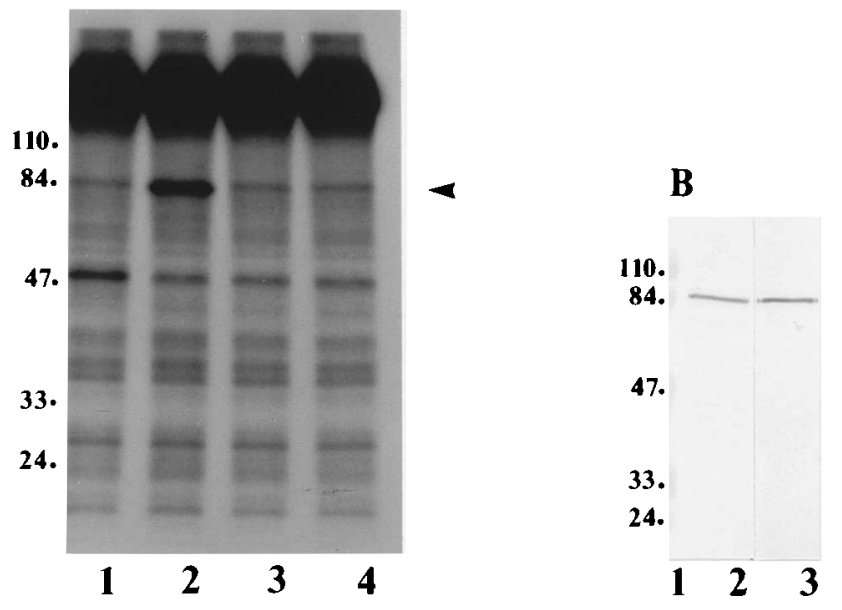

FIG. 4. In vivo linkage of L-A gag protein to cap-labeled RNA. (A) Sphero-

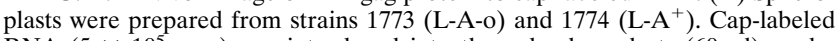
RNA $\left(5 \times 10^{5} \mathrm{cpm}\right)$ was introduced into thawed spheroplasts $(60 \mu \mathrm{l})$ as described in Materials and Methods. A portion of each clarified homogenate $(25 \%)$ was analyzed on an SDS-10\% polyacrylamide gel; an autoradiogram of the dried gel is presented. Molecular mass marker sizes (in kilodaltons) are indicated on the left of the panel, and the arrowhead on the right points to the labeled L-A Gag protein. Lanes: 1, L-A-o spheroplasts; 2, spheroplasts carrying L-A; 3, spheroplasts carrying L-A with the cap analog $\mathrm{m}^{7} \mathrm{GDP}(300 \mu \mathrm{M})$ present during both the initial and the PEG solution incubations; 4, L-A-o spheroplasts with 720 ng of purified L-A virus added at the same time as the glass beads. All of the bands except that marked by the arrow are RNase sensitive (not shown). (B) Estimate of the amount of Gag protein in spheroplasts of strain 1774 by immunoblot analysis. Samples were resolved on an SDS-10\% polyacrylamide gel, and immunoblotting was performed with an anti-Gag monoclonal antibody. The sizes of the molecular mass standards (in kilodaltons) are indicated on the left of the panel. Lanes: 1, prestained molecular mass markers; 2, thawed spheroplasts (5 $\mu \mathrm{l})$ from strain 1774 with $15 \mu \mathrm{l}$ of buffer B (10 mM HEPES [pH 7.9], $1.5 \mathrm{mM}$ $\mathrm{MgCl}_{2}, 10 \mathrm{mM} \mathrm{KCl}, 0.5 \mathrm{mM}$ phenylmethylsulfonyl fluoride); 3, $720 \mathrm{ng}$ of purified $\mathrm{L}-\mathrm{A}$ virus in $20 \mu \mathrm{l}$ of buffer $\mathrm{B}$.
mRNAs, that SKI8 is not acting primarily by degrading poly(A)-deficient RNA.

We tested the effect of a ski1/xrn1 disruption on translation of electroporated mRNAs, but because these have a $5^{\prime}$ triphosphate end, a structure that is known to be resistant to the action of the $S K I 1 / X R N 1$ exoribonuclease (53), there was, as expected, no effect (Table 1).

\section{DISCUSSION}

L-A decapitates cellular mRNAs, apparently to decoy the Ski1p (Xrn1p) exoribonuclease. The $5^{\prime}$ cap and/or $3^{\prime}$ poly(A) structures of eukaryotic mRNAs are critical at all stages of an mRNA molecule's life, including the splicing, transport, stability, and translation of mRNA. The cytoplasmic viruses L-A (and its satellites $\mathrm{M}_{1}$, etc.) and L-BC must ensure the stability and translation of their $(+)$ strands, which lack $5^{\prime}$ cap and $3^{\prime}$ poly(A) structures.

The XRN1 gene encodes a $5^{\prime} \rightarrow 3^{\prime}$ exoribonuclease that is specific for uncapped RNAs. xrn1 mutants have elevated levels of uncapped and poly(A)-deficient mRNAs $(23,37)$. A. Johnson and R. Kolodner have recently shown that $S K I 1$ is identical to XRN1 (26a). This suggests that the Xrn1p exoribonuclease

TABLE 3. ski1 suppresses mutation of Gag His-154 for expression of killer toxin ${ }^{a}$

\begin{tabular}{llll}
\hline \multicolumn{1}{c}{ Gag source } & SKI & ski1 & ski8 \\
\hline Wild-type His-154 & $++^{b}$ & ++ & ++ \\
Arg-154 & w & + & w \\
Asn-154 & w & ++ & w \\
Ser-154 & w & ++ & w \\
\hline
\end{tabular}

${ }^{a}$ The wild type (strain JR1 = MATa trp1 ura3 leu2 his3 pep4::HIS3 nuc1::LEU2 L-A-o M-o L-BC) and isogenic ski1::URA3 and ski8::URA3 disruptants carried the L-A expression plasmid pTIL131 (60) or derivatives with the indicated mutations in Gag (4). $\mathrm{M}_{1}$ was introduced by cytoduction from strain JR5 (kar1 L-A-o $\mathbf{M}_{1}$ pI2L2 [4]). Strains were grown as patches on H-trp plates to maintain selection of the plasmids. Cells were replica plated onto killersensitive lawns on $4.7 \mathrm{MB}$ medium and incubated at $20^{\circ} \mathrm{C}$ for 3 days. As previously reported (60), the L-A cDNA clone supporting $\mathrm{M}_{1}$ in a wild-type host makes cells superkillers.

${ }^{b}+$, wild-type killer; ++ , superkiller; w, weak killer. 


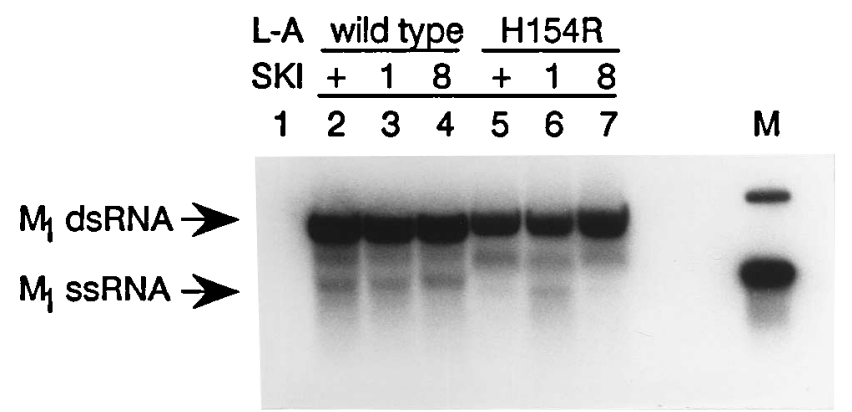

FIG. 5. Decapping-defective L-A mutant (Gag His-154 $\rightarrow$ Arg) has decreased $\mathrm{M}_{1}(+)$ strands, and this effect is relieved by disruption of skil but not of ski8. Strain JR1 cells carrying the normal L-A cDNA clone pTIL131 or the decappingdefective L-A mutant (Gag His-154 $\rightarrow$ Arg; pAB7 [4]) were made skil or ski8 by gene disruption (see Methods). Cells were grown and equal amounts of RNA were analyzed on a native agarose gel, denatured, blotted to a nylon membrane, and hybridized with an $\mathrm{M}_{1}(+)$ strand-specific probe as described in Materials and Methods. Lanes: 1, SKI ${ }^{+}$(no plasmid) M-o; 2, SKI ${ }^{+}$pTIL131 $\mathrm{M}_{1} ; 3$, ski1::URA3 pTIL131 $\mathrm{M}_{1}$; 4, ski8::URA3 pTIL131 $\mathrm{M}_{1} ; 5$, SKI ${ }^{+}$pAB7 $\mathrm{M}_{1} ; 6$, ski1::URA3 pAB7 $\mathrm{M}_{1}$; 7, ski8::URA3 pAB7 $\mathrm{M}_{1}$; $\mathrm{M}$, mixture of $\mathrm{M}_{1}$ dsRNA and ssRNA from a viral transcription reaction. The migration of $M_{1}$ dsRNA and ssRNA is indicated. The intermediate band is replication intermediate (partially double-stranded) $\mathrm{M}_{1}$ RNA.

activity acts on the uncapped viral $(+)$ ssRNAs. The L-A Gag protein has a decapitation activity that acts on any capped RNA and removes the $\mathrm{m}^{7} \mathrm{GMP}$ from the cap attaching it to His-154 of Gag $(3,4)$. When propagation of $\mathrm{M}_{1}$ dsRNA is supported by a cDNA clone of L-A, this decapping activity of Gag is necessary in wild-type cells for expression of killer toxin encoded by $\mathrm{M}_{1}(+)$ ssRNA (4). It is not necessary for expression of the L-A cDNA-encoded information, which is, of course, expressed as cap ${ }^{+} \operatorname{poly}(\mathrm{A})^{+}$mRNA. His-154 would presumably be needed for expression from the L-A virus, but methods are not yet available to test this. Here, we show directly that decapitation occurs in vivo, as indicated by the transfer of caps to Gag, the major coat protein, in spheroplasts. We find that while this activity is required for expression of killer toxin in wild-type cells, it is not required in ski1/xrn1/sep1 mutant cells. The level of $\mathrm{M}_{1}(+)$ strand RNA in vivo is, in fact, low in a wild-type strain when the Gag from the L-A cDNA clone is incapable of decapitating cellular mRNA but remains essentially normal in a skil mutant (Fig. 5), in parallel with the results of killer toxin assays. This suggests that the Gag decapitating activity reduces Xrn1p-mediated degradation of the uncapped viral mRNA by decoying the enzyme with uncapped cellular mRNAs (Fig. 6).

The decapitation-decoying mechanism we propose here differs from the cap-stealing mechanisms used by influenza virus and bunyaviruses in that those viruses remove 10 to 15 nucleotides of the mRNA along with the cap and use these as primers for synthesis of viral mRNA. In those cases, the viral message acquires a cap from the cellular message. We examined this possibility by looking for the transfer of cap label to L-A or $M_{1}$ nascent transcripts, but we were unable to detect any significant transfer. Nor can L-A carry out transfer of caps from donor mRNA to a recipient RNA supplied externally.

Can the number of decapitated cellular mRNAs justify a role in decoying Xrn1p? The in vitro decapitation reaction results in transfer of $\mathrm{m}^{7} \mathrm{GMP}$ to a substantial fraction (at least half) of the $120 \mathrm{Gag}$ molecules of each virus particle (Fig. 1 of reference 4), and the copy number of L-A is 1,000 to 5,000 per cell. The in vitro transcription reaction requires about 30 to 60 min for completion of a full-length chain (16). Thus, only about three viral $(+)$ strands would be synthesized per cell doubling

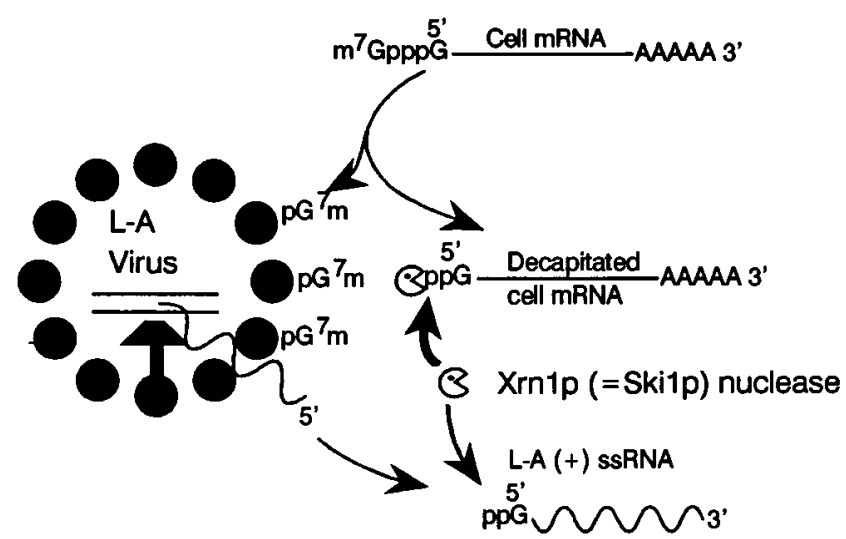

FIG. 6. Model of decapitation decoying by Gag of SKI1/XRN1 exoribonuclease. L-A Gag decapitates cellular mRNAs, and these headless cellular mRNAs become targets for the Xrn1p exoribonuclease, partially freeing the capless L-A and $\mathrm{M}_{1}$ mRNAs from attack.

per particle. Even assuming that only half of the Gag molecules could decapitate cellular mRNA and that each could act only once, at least 20 cellular mRNA molecules would be decapitated by Gag for each viral $(+)$ strand produced, potentially over 60,000 decapitated molecules produced per cell [ $60 \mathrm{ac}-$ tive Gag molecules/particle $) \times(1,000 \mathrm{~L}-\mathrm{A}$ viral particles/cell)]. These estimates rely on in vitro data and will have to be confirmed by in vivo studies. They also do not account for cellular mRNA molecules decapitated by other mechanisms. Clearly the $S K I 1 / X R N 1$ exoribonuclease is not completely swamped by the Gag decapitation, as shown by the superkiller phenotype of ski1 mutants. If the enzyme were already swamped by decapitated molecules produced by Gag, mutating the gene would not have a further effect.

5'-triphosphate-ended RNAs, such as those made by T7 RNA polymerase in our experiments, are known to be resistant to degradation by the $S K I 1 / X R N 1$ exonuclease (53), and so, as expected, a ski1/xrn1 disruption does not significantly affect translation of $\mathrm{C}^{-} \mathrm{A}^{+}$luciferase $\mathrm{mRNA}$ introduced by this method. Consistent with this result, the rate of luciferase RNA degradation in electroporated cells is relatively independent of the presence or absence of $5^{\prime}$ cap or $3^{\prime}$ poly(A) (Fig. 1). Both mRNAs decapitated by Gag action (4) and the L-A and $\mathrm{M}_{1}$ (+) strand transcripts (39) have diphosphate ends.

Ski2p, Ski3p, and Ski8p restrict translation of poly $(A)^{-}$ mRNA. The Ski proteins repress the copy number of three yeast cytoplasmic RNA replicons, the L-A virus (and its satellites), the L-BC virus, and 20S RNA (an apparently naked RNA replicon) $(1,34)$. Recent evidence suggested that Ski2p, perhaps together with other Ski proteins, acts by blocking translation of the viral mRNAs, possibly recognizing the absence of $5^{\prime}$ cap, $3^{\prime}$ poly(A), or both (62). We show here that it is specifically $3^{\prime}$ poly $(\mathrm{A})^{-}$mRNAs whose translation is blocked by Ski2p. SKI3 and SKI8 are also involved in this process, as was suggested by their mutants displaying the same range of phenotypes as ski2 $(45,56)$ and our finding that they also specifically inhibit translation of non-poly(A) mRNA. The effect of each of the Ski proteins on cap ${ }^{-}$poly $(\mathrm{A})^{-}$mRNA is two- to fivefold, and this is the same magnitude as their effect on the copy number of L-A, M, L-BC, and 20S RNAs in vivo. Each of these RNA replicons is believed to produce cap ${ }^{-}$ poly (A) ${ }^{-}$message.

The how and why of SKI2-SKI3-SKI8 action. The means by which the Ski2-Ski3-Ski8 system works is still unclear. The 
replication cycles of the L-A virus and its satellites take place mostly within the viral particles, in which both $(+)$ and $(-)$ strands are synthesized. The only point at which the genome ventures out of the particle is when new $(+)$ strand transcripts are extruded to be translated and packaged to make new particles. When the propagation of the $\mathrm{M}_{1}$ or X satellite dsRNAs is supported by an L-A cDNA clone $\left[\mathrm{cap}^{+}\right.$poly $(\mathrm{A})^{+}$transcripts], Ski2p does not lower their copy number (62). If Ski2p were degrading the $\mathrm{M}_{1}$ or $\mathrm{X}(+)$ ssRNA [presumably cap poly $\left.(\mathrm{A})^{-}\right]$, then it should repress their copy number. That it does not indicates that Ski2p blocks the translation without degrading the poly $(\mathrm{A})^{-}$RNA. We directly tested for an effect of a ski2 mutation on degradation of electroporated luciferase mRNA, and we found no effect on either the physical integrity of the RNA or the kinetics of translation of a magnitude sufficient to account for the observed translation results (Fig. 1 and 2). The initial rates of luciferase synthesis from poly(A) mRNA were 4.5- and 6.8-fold higher in ski2 and ski8 cells, respectively, than in wild-type cells. Thus, it is likely that Ski2p or proteins controlled by Ski2p affect the translation of $\operatorname{poly}(\mathrm{A})^{-}$RNA without directly affecting its degradation. We also saw no effect of ski8 on the levels of the poly(A) ${ }^{-} \mathrm{M}_{1}(+)$ ssRNA (Fig. 5), which supports this conclusion.

Ski3p is a nuclear protein, while Ski2p has a glycine-arginine-rich domain characteristic of nucleolar proteins. The human Ski2p homolog, hSki2p, is, in fact, a nucleolar protein (31). Ski3p has the TPR repeat pattern, and Ski8p has the $\beta$-transducin repeat. That these two proteins act together is one of the bases on which the TPR and $\beta$-transducin repeats have been proposed to mediate protein-protein interactions. These data suggest that the Ski2, -3 , and -8 proteins have their effects by modulating ribosome biogenesis rather than by directly recognizing the features of mRNA.

Several lines of evidence have recently suggested that the $3^{\prime}$ poly(A) structure plays a crucial role in regulating translational initiation, being important for attracting the $60 \mathrm{~S}$ subunit to join the 40 S subunit waiting at the initiator AUG $(38,47)$. The Ski proteins may be involved in this process (Fig. 7). We suggest that either Ski2p, Ski3p, or Ski8p or a protein controlled by them (Ski2cp in Fig. 7) binds to the 60S subunit to make it reluctant to bind to the $40 \mathrm{~S}$ ribosomal subunit waiting at the initiator AUG. The $3^{\prime}$ poly(A) structure, perhaps via the poly(A)-binding protein, ejects Ski2cp from this site, and 60S subunit binding to the $40 \mathrm{~S}$ subunit proceeds. Alternatively, Ski2cp may be involved in the biosynthesis of this site on the $60 \mathrm{~S}$ subunit and may be necessary for the 60S subunit to require interaction with the $3^{\prime}$ poly(A).

The chromosomal $M A K$ genes are necessary for $\mathrm{M}_{1}$ dsRNA propagation. Prompted by our finding that three $M A K$ genes encode proteins of the large ribosomal subunit $(M A K 8=\mathrm{L} 3$, $M A K 7=\mathrm{L} 4, M A K 18=\mathrm{L} 41[9,40,61])$, we have recently found that mutants in 20 of the $27 M A K$ genes examined have a marked decrease in free $60 \mathrm{~S}$ ribosomal subunits $(9,40)$. Because the $3^{\prime}$ poly(A) structure is believed to enhance association of the $60 \mathrm{~S}$ subunit with the $40 \mathrm{~S}$ subunit waiting at the initiator AUG (38), a decrease in free 60S subunits should be more detrimental to translation of the poly $(\mathrm{A})^{-}$viral mRNAs than to translation of the poly $(\mathrm{A})^{+}$cellular mRNAs. This explains why these mak mutants lose $\mathrm{M}_{1}$ dsRNA and have a decreased L-A dsRNA copy number.

We suggest here that ski2, ski3, or ski8 mutants have 60S subunits that have a reduced requirement for the interaction with the $3^{\prime}$ poly(A) before they will join with the 40S subunit waiting at the initiator AUG. This predicts that ski2, ski3, or ski8 mutations should suppress the mak mutations affecting

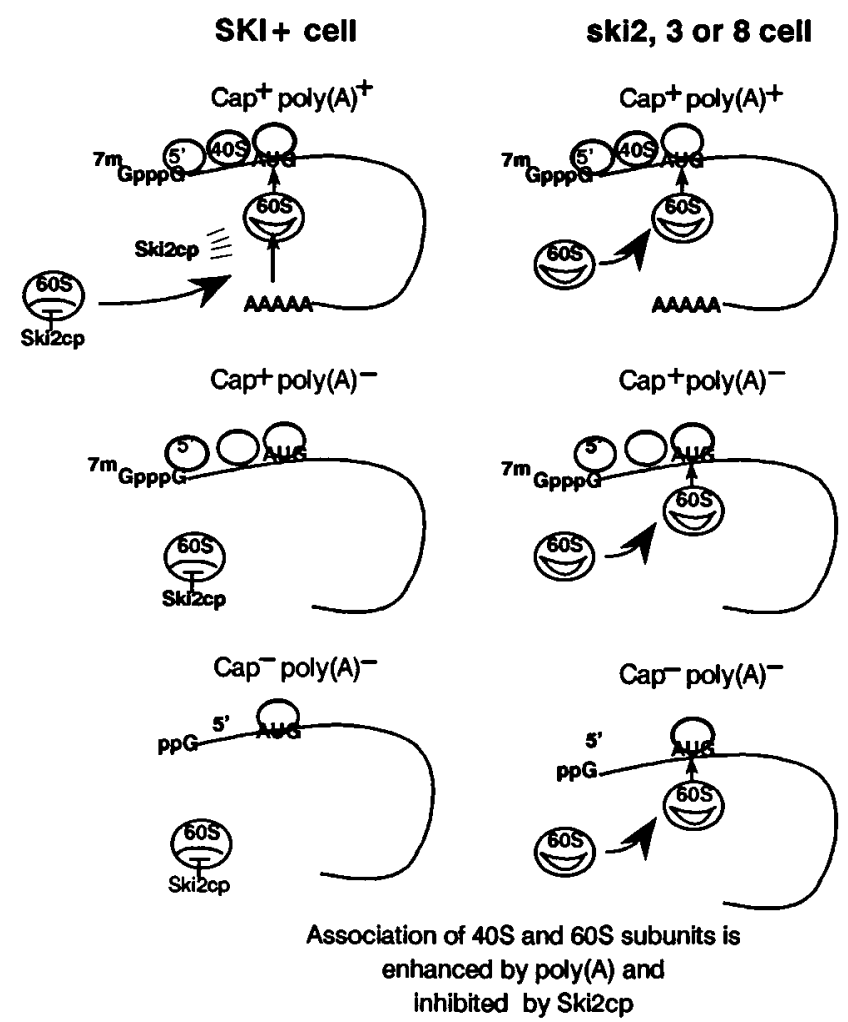

FIG. 7. Model of Ski2,3,8p system surveillance of poly(A) ${ }^{-}$mRNA. We suggest that Ski2,3,8p or a Ski2,3,8p-controlled protein (Ski2cp in the diagram) interacts with the site on $60 \mathrm{~S}$ ribosomal subunits that is the target of poly(A) or poly(A)-binding protein action. Ski2cp inhibits the 60S subunit interaction with the 40 S subunit waiting at the AUG, thus blocking translation of poly(A) ${ }^{-}$RNA. The interaction with poly(A) [or poly(A)-associated proteins] displaces Ski2cp and makes the 60S subunit ready to interact with the $40 \mathrm{~S}$ subunit. Alternatively, Ski2p may be involved in biogenesis of $60 \mathrm{~S}$ subunits, acting to make them require stimulation by poly(A) or a poly(A)-binding protein(s) before they can join the $40 \mathrm{~S}$ subunit on the mRNA.

$60 \mathrm{~S}$ subunit levels. This has, in fact, long been known to be the case (57), supporting our interpretation.

We further tested our model here by examining the polysome profiles of $\mathrm{mak}^{-} s k i^{-}$double mutants. Our model predicts that a ski2 mutation should correct the inability of a mak7 mutant to propagate $M_{1}$ without correcting the deficiency in 60S subunits. This proved to be the case (Fig. 3), supporting our view.

While the Ski2, -3 , and -8 proteins have an 18- to 34 -fold effect on cap $^{+}$poly $(\mathrm{A})^{-}$mRNA, there is only a 2- to 5-fold effect on the translation efficiency of cap ${ }^{-} \operatorname{poly}(\mathrm{A})^{-}$luciferase mRNA (Table 1), an effect similar in magnitude to that seen on expression of the presumably cap ${ }^{-}$poly $(\mathrm{A})^{-}$RNA polymerase I transcripts of lac $Z$ (62) and on the copy numbers of the various RNA replicons. Because the absence of the 5' cap should produce a markedly slower rate of loading of $40 \mathrm{~S}$ subunits, we suppose that the efficiency with which 60S subunits bind to the 40S subunits waiting at the AUG is not as rate limiting for $\mathrm{cap}^{-} \operatorname{poly}(\mathrm{A})^{-}$mRNA as it is for $\mathrm{cap}^{+} \operatorname{poly}(\mathrm{A})^{-}$ mRNA.

The only essential function of any of the $S K I 2,-3,-4,-6,-7$, or -8 genes is to control viral propagation. Control of the copy number of $\mathrm{M}_{1}$ is critical and mutant ski $\mathrm{M}_{1}$ strains are cold sensitive for growth or, if they also carry the non-Mendelian element [D], grow poorly at any temperature $(14,45)$. Our finding that Ski2p blocks the translation of $\operatorname{cap}^{+} \operatorname{poly}(\mathrm{A})^{-}$ 
RNA suggests that it may also function in blocking the translation of partially degraded cellular mRNAs. This is apparently not an essential function.

The L-BC dsRNA virus has a single genomic segment the same size as L-A but has no homology to L-A by hybridization (50). Its replication cycle resembles that of L-A (17), and like L-A its copy number is repressed by Ski proteins (1). Its major coat protein also covalently binds cap structures (3). L-BC may, like L-A, use a decapitated-decoy strategy, but this has not yet been tested.

The $5^{\prime}$ cap and $3^{\prime}$ poly(A) structures are important at nearly all stages of the life of a cellular mRNA. The lengths to which viruses go to synthesize or steal caps, or, in the case of L-A, to decoy the host cap ${ }^{-}$mRNA-degrading enzyme(s), and the properties of the ski mutants suggest that one of the important functions of these structures, particularly the $3^{\prime} \operatorname{poly}(\mathrm{A})$, is as part of the cell's defense against viral infection. Cellular mRNAs are labeled as self with the cap and poly(A) structures.

Members of the family Reoviridae, like L-A, make poly(A) ${ }^{-}$ mRNA. Is the SKI system a special feature that allows the L-A virus and yeast to live happily together? Or are members of the family Reoviridae subject to a similar host restriction of translation but have found a way to circumvent it, possibly with the aid of the oligo(A) they carry with them in the virion, as has been suggested (38)? The recent discovery of a mammalian homolog of SKI2 (31) suggests a closer parallel between these viral systems than may have been suspected.

\section{ACKNOWLEDGMENTS}

We thank Daniel Gallie for providing the luciferase and glucuronidase plasmids and Arlen Johnson for the SEP1 disruption plasmid.

\section{REFERENCES}

1. Ball, S. G., C. Tirtiaux, and R. B. Wickner. 1984. Genetic control of L-A and L-BC dsRNA copy number in killer systems of Saccharomyces cerevisiae. Genetics 107:199-217.

2. Bishop, D. H. L., M. E. Gay, and Y. Matsuoko. 1983. Nonviral heterogeneous sequences are present at the $5^{\prime}$ ends of one species of snowshoe hare bunyavirus S complementary RNA. Nucleic Acids Res. 11:64096418.

3. Blanc, A., C. Goyer, and N. Sonenberg. 1992. The coat protein of the yeast double-stranded RNA virus L-A attaches covalently to the cap structure of eukaryotic mRNA. Mol. Cell. Biol. 12:3390-3398.

4. Blanc, A., J. C. Ribas, R. B. Wickner, and N. Sonenberg. 1994. His-154 is involved in the linkage of the Saccharomyces cerevisiae L-A double-stranded RNA virus Gag protein to the cap structure of mRNAs and is essential for $\mathrm{M}_{1}$ satellite virus expression. Mol. Cell. Biol. 14:2664-2674.

5. Bouloy, M., S. J. Plotch, and R. M. Krug. 1978. Globin mRNAs are primers for the transcription of influenza viral RNA in vitro. Proc. Natl. Acad. Sci. USA 75:4886-4890.

6. Bruenn, J., and B. Keitz. 1976. The $5^{\prime}$ ends of yeast killer factor RNAs are pppGp. Nucleic Acids Res. 3:2427-2436.

7. Bruenn, J. A., and V. E. Brennan. 1980. Yeast viral double-stranded RNAs have heterogeneous $3^{\prime}$ termini. Cell 19:923-933.

8. Bussey, H. 1991. K1 killer toxin, a pore-forming protein from yeast. Mol. Microbiol. 5:2339-2343.

9. Carroll, K., and R. B. Wickner. Translation and $M_{1}$ double-stranded RNA: $M A K 18=R P L 41 B$ and cycloheximide curing. J. Bacteriol., in press.

10. Carter, C., C. M. Stoltzfus, A. K. Banerjee, and A. J. Shatkin. 1974. Origin of reovirus oligo(A). J. Virol. 13:1331-1337.

11. Cleveland, D. R., H. Zarbl, and S. Millward. 1986. Reovirus guanylyltransferase is L2 gene product lambda 2. J. Virol. 60:307-311.

12. Dihanich, M., E. Van Tuinen, J. D. Lambris, and B. Marshallsay. 1989. Accumulation of viruslike particles in a yeast mutant lacking a mitochondrial pore protein. Mol. Cell. Biol. 9:1100-1108.

13. Dinman, J. D., T. Icho, and R. B. Wickner. 1991. A-1 ribosomal frameshift in a double-stranded RNA virus of yeast forms a gag-pol fusion protein. Proc. Natl. Acad. Sci. USA 88:174-178.

14. Esteban, R., and R. B. Wickner. 1987. A new non-mendelian genetic element of yeast that increases cytopathology produced by M1 double-stranded RNA in ski strains. Genetics 117:399-408.

15. Everett, J. G., and D. R. Gallie. 1992. RNA delivery in Saccharomyces cerevisiae using electroporation. Yeast 8:1007-1014.
16. Fujimura, T., R. Esteban, and R. B. Wickner. 1986. In vitro L-A doublestranded RNA synthesis in virus-like particles from Saccharomyces cerevisiae. Proc. Natl. Acad. Sci. USA 83:4433-4437.

17. Fujimura, T., and R. B. Wickner. 1987. L-A double-stranded RNA viruslike particle replication cycle in Saccharomyces cerevisiae: particle maturation in vitro and effects of mak10 and pet18 mutations. Mol. Cell. Biol. 7:420-426.

18. Fujimura, T., and R. B. Wickner. 1988. Gene overlap results in a viral protein having an RNA binding domain and a major coat protein domain. Cell 55:663-671.

19. Furuichi, Y., S. Muthukrishnan, S. Tomasz, and A. J. Shatkin. 1976. Mechanism of formation of reovirus mRNA 5'-terminal blocked and methylated sequence ${ }^{\mathrm{m} 7} \mathrm{GpppG} \mathrm{G}^{\mathrm{m}}$ pC. J. Biol. Chem. 251:5043-5053.

20. Gallie, D. R. 1991. The cap and poly(A) tail function synergistically to regulate mRNA translational efficiency. Genes Dev. 5:2108-2116.

21. Gallie, D. R., J. N. Feder, R. T. Schimke, and V. Walbot. 1991. Post transcriptional regulation in higher eukaryotes: the role of the reporter gene in controlling expression. Mol. Gen. Genet. 228:258-264.

22. Hartwell, L. H., and C. S. McLaughlin. 1968. Temperature-sensitive mutants of yeast exhibiting a rapid inhibition of protein synthesis. J. Bacteriol. 96: 1664-1671.

23. Hsu, C. L., and A. Stevens. 1993. Yeast cells lacking $5^{\prime} \rightarrow 3^{\prime}$ exoribonuclease 1 contain mRNA species that are poly(A) deficient and partially lack the $5^{\prime}$ cap structure. Mol. Cell. Biol. 13:4826-4835.

24. Icho, T., and R. B. Wickner. 1989. The double-stranded RNA genome of yeast virus L-A encodes its own putative RNA polymerase by fusing two open reading frames. J. Biol. Chem. 264:6716-6723.

25. Jackson, R. J., and N. Standart. 1990. Do the poly(A) tail and 3 ' untranslated region control mRNA translation? Cell 62:15-24.

26. Jang, S. K., H.-G. Kräusslich, M. J. H. Nicklin, G. M. Duke, A. C. Palmenberg, and E. Wimmer. 1988. A segment of the 5' nontranslated region of encephalomyocarditis virus RNA directs internal entry of ribosomes during in vitro translation. J. Virol. 62:2636-2643.

26a.Johnson, A., and R. Kolodner. Personal communication.

27. Kim, J., P. O. Ljungdahl, and G. R. Fink. 1990. kem mutations affect nuclear fusion in Saccharomyces cerevisiae. Genetics 126:799-812.

28. Kingsbury, D. W. 1990 . Orthomyxoviridae and their replication, p. 1075 1089. In B. N. Fields and D. M. Knipe (ed.), Fields' virology, vol. 1. Raven Press, New York.

29. Kipling, D. C. Tambini, and S. E. Kearsey. 1991. rar mutations which increase artificial chromosome stability in Saccharomyces cerevisiae identify transcription and recombination proteins. Nucleic Acids Res. 19:1385-1391.

30. Larimer, F. W., C. L. Hsu, M. K. Maupin, and A. Stevens. 1992. Characterization of the XRN1 gene encoding a $5^{\prime} \rightarrow 3^{\prime}$ exoribonuclease: sequence data and analysis of disparate protein and mRNA levels of gene-disrupted cells. Gene 120:51-57.

31. Lee, S.-G., I. Lee, C. Kang, and K. Song. Identification and characterization of a human cDNA homologous to yeast SKI2. Genomics, in press.

32. Lejbkowicz, F., C. Goyer, A. Darveau, S. Neron, R. Lemieux, and N. Sonenberg. 1992. A fraction of the $5^{\prime}$ cap-binding protein, eukaryotic initiation factor 4E, localizes to the nucleus. Proc. Natl. Acad. Sci. USA 89:9612-9616.

33. Liu, D. X., and S. C. Inglis. 1992. Internal entry of ribosomes on a tricistronic mRNA encoded by infectious bronchitis virus. J. Virol. 66:6143-6154.

34. Matsumoto, Y., R. Fishel, and R. B. Wickner. 1990. Circular single-stranded RNA replicon in Saccharomyces cerevisiae. Proc. Natl. Acad. Sci. USA 87: 7628-7632.

35. Matsumoto, Y., G. Sarkar, S. S. Sommer, and R. B. Wickner. 1993. A yeast antiviral protein, $S K I 8$, shares a repeated amino acid sequence pattern with beta-subunits of $\mathrm{G}$ proteins and several other proteins. Yeas 8:43-51.

36. Matsumoto, Y., and R. B. Wickner. 1991. Yeast 20 S RNA replicon. Replication intermediates and encoded putative RNA polymerase. J. Biol. Chem. 266:12779-12783.

37. Muhlrad, D., and R. Parker. 1994. Premature translational termination triggers mRNA decapping. Nature (London) 370:578-581.

38. Munroe, D., and A. Jacobson. 1990. Tales of poly(A): a review. Gene 91: 151-158.

39. Nemeroff, M. E., and J. A. Bruenn. 1987. Initiation by the yeast viral transcriptase in vitro. J. Biol. Chem. 262:6785-6787.

40. Ohtake, Y., and R. B. Wickner. 1995. Yeast virus propagation depends critically on free $60 \mathrm{~S}$ ribosomal subunit concentration. Mol. Cell. Biol. 15: 2772-2781.

41. Patterson, J. L., B. Holloway, and D. Kolakofsky. 1984. La Crosse virion contain a primer-stimulated RNA polymerase and a methylated cap-dependent endonuclease. J. Virol. 52:215-222.

42. Pelletier, J., and N. Sonenberg. 1988. Internal initiation of translation of eukaryotic mRNA directed by a sequence derived from poliovirus RNA. Nature (London) 334:320-325.

43. Plotch, S. J., M. Bouloy, I. Ulmanen, and R. M. Krug. 1981. A unique cap $(\mathrm{m} 7 \mathrm{GpppXm})$-dependent influenza virion endonuclease cleaves capped RNAs to generate the primers that initiate viral RNA transcription. Cell 23:847-858 
44. Rhee, S. K., T. Icho, and R. B. Wickner. 1989. Structure and nuclear localization signal of the SKI3 antiviral protein of Saccharomyces cerevisiae. Yeast 5:149-158.

45. Ridley, S. P., S. S. Sommer, and R. B. Wickner. 1984. Superkiller mutations in Saccharomyces cerevisiae suppress exclusion of $\mathrm{M}_{2}$ double-stranded RNA by L-A-HN and confer cold sensitivity in the presence of M and L-A-HN. Mol. Cell. Biol. 4:761-770.

46. Russell, P. J., S. J. Hambidge, and K. Kirkegaard. 1991. Direct introduction and transient expression of capped and non-capped RNA in Saccharomyces cerevisiae. Nucleic Acids Res. 19:4949-4953.

47. Sachs, A. B., and R. W. Davis. 1989. The poly(A) binding protein is required for poly(A) shortening and $60 \mathrm{~S}$ ribosomal subunit-dependent translation initiation. Cell 58:857-867.

48. Scheidel, L. M., R. K. Durbin, and V. Stollar. 1989. SVLM21, a Sindbis virus mutant resistant to methionine deprivation, encodes an altered methyltransferase. Virology 173:408-414.

49. Sikorski, R. S., M. S. Boguski, M. Goebl, and P. Hieter. 1990. A repeating amino acid motif in $C D C 23$ defines a family of proteins and a new relationship among genes required for mitosis and RNA synthesis. Cell 60:307-317.

50. Sommer, S. S., and R. B. Wickner. 1982. Yeast L dsRNA consists of at least three distinct RNAs: evidence that the non-Mendelian genes [HOK], [NEX] and [EXL] are on one of these dsRNAs. Cell 31:429-441.

51. Sommer, S. S., and R. B. Wickner. 1987. Gene disruption indicates that the only essential function of the SKI8 chromosomal gene is to protect Saccharomyces cerevisiae from viral cytopathology. Virology 157:252-256.

52. Stevens, A. 1980. Purification and characterization of a Saccharomyces cerevisiae exoribonuclease which yields $5^{\prime}$ mononucleotides by a $5^{\prime} \rightarrow 3^{\prime}$ mode of hydrolysis. J. Biol. Chem. 255:3080-3085.

53. Stevens, A., and M. K. Maupin. 1987. A $5^{\prime} \rightarrow 3^{\prime}$ exoribonuclease of Saccharomyces cerevisiae: size and novel substrate specificity. Arch. Biochem. Bio- phys. 252:339-347

54. Thiele, D. J., E. M. Hannig, and M. J. Leibowitz. 1984. Multiple L doublestranded RNA species of Saccharomyces cerevisiae: evidence for separate encapsidation. Mol. Cell. Biol. 4:92-100.

55. Tishkoff, D. X., A. W. Johnson, and R. D. Kolodner. 1991. Molecular and genetic analysis of the gene encoding the Saccharomyces cerevisiae strand exchange protein Sep1. Mol. Cell. Biol. 11:2593-2608.

56. Toh-e, A., P. Guerry, and R. B. Wickner. 1978. Chromosomal superkiller mutants of Saccharomyces cerevisiae. J. Bacteriol. 136:1002-1007.

57. Toh-e, A., and R. B. Wickner. 1980. "Superkiller" mutations suppress chromosomal mutations affecting double-stranded RNA killer plasmid replication in Saccharomyces cerevisiae. Proc. Natl. Acad. Sci. USA 77:527-530.

58. Wagner, R. R. 1990. Rhabdoviridae and their replication, p. 867-881. In B. N. Fields and D. M. Knipe (ed.), Fields' virology, vol. 1. Raven Press, New York.

59. Wickner, R. B. 1992. Double-stranded and single-stranded RNA viruses of Saccharomyces cerevisiae. Annu. Rev. Microbiol. 46:347-375.

60. Wickner, R. B., T. Icho, T. Fujimura, and W. R. Widner. 1991. Expression of yeast L-A double-stranded RNA virus proteins produces derepressed replication: a $s k i^{-}$phenocopy. J. Virol. 65:155-161.

61. Wickner, R. B., S. P. Ridley, H. M. Fried, and S. G. Ball. 1982. Ribosomal protein L3 is involved in replication or maintenance of the killer doublestranded RNA genome of Saccharomyces cerevisiae. Proc. Natl. Acad. Sci. USA 79:4706-4708.

62. Widner, W. R., and R. B. Wickner. 1993. Evidence that the $S K I$ antivira system of Saccharomyces cerevisiae acts by blocking expression of viral mRNA. Mol. Cell. Biol. 13:4331-4341.

63. Zhu, Y.-S., J. Kane, X.-Y. Zhang, M. Zhang, and D. J. Tipper. 1993. Role of the $\gamma$ component of preprotoxin in expression of the yeast $\mathrm{K}_{1}$ killer phenotype. Yeast 9:251-266. 